\title{
Comparison of properties of prefabricated interlocking pavement blocks cured at different conditions
}

\section{Comparación de propiedades de enclavamiento bloques prefabricados pavimento curado en diferentes condiciones}

Tayfun Uygunoğlu (Main and Contact Author)

Afyon Kocatepe University, Engineering Faculty, Civil Engineering Department

03200, Afyonkarahisar, Turkey, Tel: 902722281312 , Fax: 902722281319

uygunoglu@aku.edu.tr

Manuscript Code: 660

Date of Acceptance/Reception: 01.08.2016/13.07.2015

\begin{abstract}
In this study, influence of curing condition and fly ash content on properties of pre-fabricated concrete interlocking blocks (PCIBs) were investigated. The blocks were produced with crushed sand stone (fine) and crushed stone (coarse) as aggregate. Also, fly ash was added to mixtures in different ratio by replacing the cement from 0 to $30 \%$. PCIBs were cured in three different types as steam cure, water-pool cure and wet cure. Compressive strength, tensile splitting strength, density, apparent porosity, water absorption by weight and abrasion resistance of PCIBs was determined. When comparing the PCIBs, the use of wet cure results in lower physical and mechanical properties after 28 days. By contrast, waterpool and steam cure gives better result on mechanical and physical properties. Also, replacement of cement with fly ash (from $10 \%$ to $20 \%$ ) has a significant effect in increasing important properties of PCIBs.
\end{abstract}

Keywords: Curing; pavement blocks; prefabricated; strength; mineral admixture.

Resumen

En este estudio, la influencia de la curación de la condición y el contenido de cenizas volantes sobre las propiedades del hormigón prefabricado Bloques entrelazados (PCIBs) fueron investigados. Los bloques fueron producidos con arena de piedra triturada (fina) y piedra triturada (grueso) como agregado. Además, cenizas fueron añadidas a las mezclas en diferente relación, reemplazando el cemento desde 0 a $30 \%$. Los PCIBs fueron curados en tres tipos diferentes como: cura de vapor, piscina de agua cura y cura húmeda. Resistencia a la compresión, resistencia a la tracción indirecta, densidad, porosidad aparente, absorción de agua por el peso y la resistencia a la abrasión de PCIBs fue determinadas. Cuando se comparan los PCIBs, el uso de la cura húmeda se traduce en la reducción de propiedades físicas y mecánicas, después de 28 días. Por el contrario, la piscina de agua y vapor cura da mejor resultado en las propiedades mecánicas y físicas. Además, la sustitución de cemento con ceniza volante (del $10 \%$ al 20\%) tiene un efecto significativo en el aumento de propiedades importantes de PCIBs.

Palabras Claves: curado; bloques de pavimento; prefabricado; fuerza; adición mineral.

Introduction

The main benefit of concrete pavement blocks over other materials is that individual pavements can later be lifted up and replaced. Rapid curing techniques are widely used in the production of pre-cast concrete pavement blocks because it accelerates the rate of strength development (Topcu and Uygunoglu, 2007). Some pre-cast concrete plants apply steam curing immediately after casting the elements in the formwork in order to speed up the production rate (Erdem, Turanli \& Erdogan, 2003). Steam curing is a heat treatment which has been used for many years to accelerate the strength development of concrete products. For compressive strength development of concrete, duration of steam curing is also an important parameter as well as temperature (Turkel and Alabas, 2005; Yang, Zhang, Huang \& He, 2000; Liu, Xie \& Li, 2005).

Fly ash, also known as industrial waste, is produced from burning coal in the thermal power plants. Today, worldwide annual production of coal fly ash is estimated around 500 million tones, constituting about $75-80 \%$ of the total coal ash production. Therefore, the amount of coal fly ash has been increasing throughout the world (Ahmaruzzaman 2010). Alike, fly ash has been produced more than 15 million tons by coal power plants in Turkey (Gesoglu, Oz and Guneyisi, 2012). The fly ash are the widely used in structural engineering materials due to their unique characteristics such as fine particle size, spherical particle shape, low carbon content and high pozzolanic reaction, resistance to weathering and etc. (Chindaprasirt, Jaturapitakkul \& Sinsiri, 2005; Zeng et al., 2012). Because of these properties, the fly ash is frequently used for industry such as: additive materials of cement, fine aggregate, filling materials etc (Yazıcı and Arel, 2012). 
Strength development of concrete pavements at early age is often inadequate for prefabrication purposes since the hardening process and strength-gaining rate of concrete under normal curing conditions are rather slow. Therefore, the curing method used for precast concrete products differs from the normal curing method where steam curing is usually employed because it accelerates the rate of strength development (Topcu and Uygunoglu, 2007). Atmospheric pressure steam curing was used to improve compressive strength of concrete pavements. The most important improvement is product ready for use within $24 \mathrm{~h}$ (the strength is generally equivalent to 28 days under ambient curing). However, this curing method alters the properties of the resulting concrete (American Concrete Institute 1963; Boukendakdji, Brooks and Wainwright, 1996; Ho, Chua \& Tam, 2003; Erdem, Turanli \& Erdogan, 2003). Although plenty information is already available on the effect of steam curing on conventional concrete properties, there is limited data relating with steam cured concrete pavement blocks prepared with fly ash. Therefore, this paper presents the results of a current study on the use of fly ash as a cement rehoplacement in steam cured interlocking concrete pavements.

Several researchers demonstrated that the use of high volume fly ash in high-performance high-strength concrete (Rong, Sun, W \& Zhang, 2010; Papayianni \& Anastasiou, 2010). The results of some mechanical properties carried out on frame concrete by Zhen-Shuang (2011) put forth that fly ash addition to concrete results in significant improvements in the compressive strength and flexural tensile strength mortar matrix at 56 days and 90 days, while the compressive strength and flexural tensile strength of mortar matrix decreases with increasing amount of fly ash on 28 days, i.e. at early ages. Bilgin et al. (2012) investigated the usage of marble wastes for the production of industrial bricks has significant important role on the recycling waste marble powder in the brick production along with a great contribution to economy and ecology of the country. They observed that the amount of marble dust additive had positive effect on the physical, chemical and mechanical strength of the produced industrial brick. Investigation of the relations between fly ash, natural stone wastes and concrete wastes various mechanical strength parameters of interlocking blocks has been the subject of a number of investigations (Gencel, Ozel, Filiz \& Koksal, 2012). The results of these investigations have indicated that the comparing the PCIBs with crushed sand stone, the replacement of crushed sand stone with concrete waste and marble waste results with lower physical and mechanical properties. By contrast, replacement of cement with fly ash (from $10 \%$ to $20 \%$ ) has a significant effect in increasing important properties of PCIBs (Uygunoglu, Topcu, Gencel \& Brostow, 2012).

Methodology

\section{Materials}

Ordinary Portland cement (OPC) was used with a minimum strength of $45 \mathrm{MPa}$ at 28 days (CEM I). Its specific gravity was 3.07. Initial and final setting times of the OPC were 300 and $530 \mathrm{~min}$, respectively. The Blaine specific surface area was $3212 \mathrm{~cm} 2 / \mathrm{g}$. Characteristic properties of OPC are presented in Table 1 . In the production of pavement blocks, mainly two groups of aggregate were used as fine and coarse. Fine aggregate was crushed sand stone in size of $0 / 6$ $\mathrm{mm}$ with specific gravity of 2.66. It was used in all the types of PCIBs. The coarse aggregates were crushed limestone with maximum size of $12 \mathrm{~mm}$. The specific gravity of the crushed limestone aggregate was 2.70 .

The fly ash was supplied from Tunçbilek, Kütahya/Turkey Thermal Power, and it was classified as $\mathrm{F}$ type according to the ASTM C 618 (2005) criterion. The Blaine fineness, which is defined as a measure of the particle size or fineness of supplementary cementitious materials, was $3226 \mathrm{~cm} 2 / \mathrm{g}$ for fly ash. Its specific gravity was $1.99 \mathrm{~g} / \mathrm{cm} 3$. The chemical composition of fly ash was given in Table 1.

Table 1. Chemical component of Portland cement (OPC) and fly-ash. Source: self-elaboration.

\begin{tabular}{ccccccccccc}
\hline \multicolumn{8}{c}{ Table 1. Chemical component of Portland cement (OPC) and fly-ash. Source: self-elaboration. } \\
\hline Oxide, \% & $\mathrm{CaO}$ & $\mathrm{SiO}_{2}$ & $\mathrm{Al}_{2} \mathrm{O}_{3}$ & $\mathrm{Fe}_{2} \mathrm{O}_{3}$ & $\mathrm{MgO}$ & $\mathrm{SO}_{3}$ & $\mathrm{~K}_{2} \mathrm{O}$ & $\mathrm{Na}_{2} \mathrm{O}$ \\
\hline OPC & 63.56 & 19.3 & 5.57 & 3.46 & 0.86 & 2.96 & 0.8 & 0.13 \\
\hline Fly ash & 0.67 & 46.51 & 25.47 & 4.88 & 5.94 & 1.7 & 1.35 & 0.36 & 2.78 \\
\hline
\end{tabular}




\section{Mix Design}

In the study, mainly two parts of PCIBs were compared. The first part aimed to evaluate the influence of the type of curing process on the properties of the PCIBs. The second part aimed at the determination of the effects of fly ash content on the properties of blocks prepared with different types of aggregates. Totally, 12 series of concrete interlocking pavement blocks were prepared with fly ash content of $0,10,20$ and $30 \%$ by replacement ratio of OPC by weight, with three types of cure condition. Effective water to binder ratio was 0.43 ; however, chemical admixture in ratio of $1 \%$ of binder was used in all the series. The binder content was kept as $230 \mathrm{~kg} / \mathrm{m} 3$. The aggregate content of the specimens consisted as $30 \%$ coarse and $70 \%$ fine aggregate. The composition of the mixes is presented in Table 2 .

Table 2. Materials content for per cubic meter. Source: self-elaboration.

\begin{tabular}{|c|c|c|c|c|c|c|}
\hline \multirow{2}{*}{ Mixes } & \multicolumn{5}{|c|}{ Materials, $\mathrm{kg} / \mathrm{m}^{3}$} & \multirow[b]{2}{*}{ Admixture } \\
\hline & Cement & Fly ash & Water & Coarse aggregates & Fine aggregate & \\
\hline M1 & 230 & 0 & 99 & 653 & 1501 & 2.30 \\
\hline M2 & 207 & 23 & 99 & 649 & 1493 & 2.30 \\
\hline M3 & 184 & 46 & 99 & 646 & 1484 & 2.30 \\
\hline M4 & 161 & 69 & 99 & 642 & 1475 & 2.30 \\
\hline
\end{tabular}

\section{Fabrication of PCIB}

In Turkey, wet-mixing of the prefabricated concrete most commonly takes place in a stationary batch type of mixer at a central plant. The concrete pavement blocks were fabricated according to ASTM C936 (2015) using a wet-mixed method. The sieved aggregates were mixed with the cementitious materials in different proportions. A 250 I batch was prepared for all mortar mixtures using a pan. The mixing sequence consisted of homogenizing the coarse and fine aggregates and binder for $1 \mathrm{~min}$ dry, and then adding water to the mixing container. The concrete mixture was mixed for $3 \mathrm{~min}$. Then blocks in size of $165 \times 200 \times 80 \mathrm{~mm}$ were fabricated in steel molds using a dry-mixing method with the actual industrial production block machine. In other words, the mixes were prepared with water only sufficient to produce a cohesive mix but with no slump/workability. The mixes were prepared in a factory machine using pressure (in ratio of 20\%) and vibration simultaneously until complete compaction was obtained. The blocks were de-moulded immediately afterwards and cured in different type.

\section{Curing process}

In order to compare the effects of the curing process, the blocks were divided into three sets as following: Steam cure: In this type of curing process, the blocks were cured at atmospheric pressure steam cure for 8 hours at 65 oC. The relative humidity was $98 \%$. One of the set of blocks was covered with plastic nylon, and the steam was supplied by steam machine. The blocks were waited in the factory until test days as 3, 7, 28 and 90 days in closed area after steam cure. Water cure: In another of the set was stored in water pool for 3, 7, 28 and 90 days. The temperature of water was kept at $200 \mathrm{C}$. The relative humidity was $100 \%$. Wet cure: In last set, water at about $170 \mathrm{C}$ was sprayed every $24 \mathrm{~h}$ for 7 days in a closed area. Then they were waited in air condition till experiment days as 3, 7, 28 and 90 days. The relative humidity was $65 \%$.

\section{Test Methods}

Several tests were applied to determine the compressive strength, splitting strength, density, water absorption by weight, specific porosity and abrasion resistance of the PCIB. All the results below are the average of three specimens. The compressive strength and splitting tensile strength were defined according to TS EN 12390-3 (2010) and TS 2824 EN 1338 (2009) standards, respectively, by hydraulic compressive machine with a rate of loading controller. The compressive strength was tested on specimens aged 3, 7, 28 and 90 days; however, splitting tensile strength of PCIBs was tested on specimens aged 3, 7 and 28 days. The load was applied to the nominal area of paving blocks. The compressive strength was calculated by dividing the failure load by the loading area of the PCIB. Density, specific porosity and water absorption were determined on the produced paving blocks aged 28 days according to Archimedes principle by the weight measurements of saturated specimens in air and in water, and dry weight (oven drying at $1050 C$ to constant weight). 
PCIB specimens were subjected to abrasion testing at 28 days after casting according to TS 2824 EN 1338 standard. Before testing, specimens were dried in an oven at $105 \pm 5$ oC until reaching a constant weight. $142.5 \mathrm{~N}$ loads were applied to the specimens in the abrasion system. The length and diameter of disc was 70 and $200 \mathrm{~mm}$, respectively. In the test procedure, $1 \mathrm{I}$ of corundum-crystalline powder was flowed between the disc and the specimen from powder box, and the disc was rotated with a rotational velocity of $75 \mathrm{rpm}$ for $1 \mathrm{~min}$ for each specimen. After that, the length loss due to wear was measured from the three points on the specimens, and the averages of these measurements were determined for each specimen. Also, fractured surfaces of PCIB chips were coated with gold in a vacuum evaporator. They were examined using a LEO VP-1431 scanning electron microscope (SEM) to determine morphological and mineralogical features.

Results and Discussions

\section{Compressive strength}

Evaluation of the experimental data, concerning the relation between compressive strength of PCIBs after stem-cure and fly ash addition are presented in Figure 1 for pavement ages. Generally, the specimens cured in water at 90 ages have higher compressive strength than that cured in steam for all FA contents. However, the compressive strength of PCIBs cured in steam has higher values than that of cured in water and wet at the early ages when the wet and water cure is more effective on compressive strength of specimens than steam curing at days later. From the strength development dates, it can be noted that the wet and water cure process is better than steam after 28 days. In 90 days, the loss of strength occurred at steam cured specimens because of some unstable forms in concrete microstructure. This behavior is identical to normal concrete that cured in steam. After steam cure, the hydration forms probably have developed by humidity at early ages. But, on increasing the hydration time, irregular distribution of hydrated cement products could occur in the steam cured specimens due to the effect of high temperature in curing process.
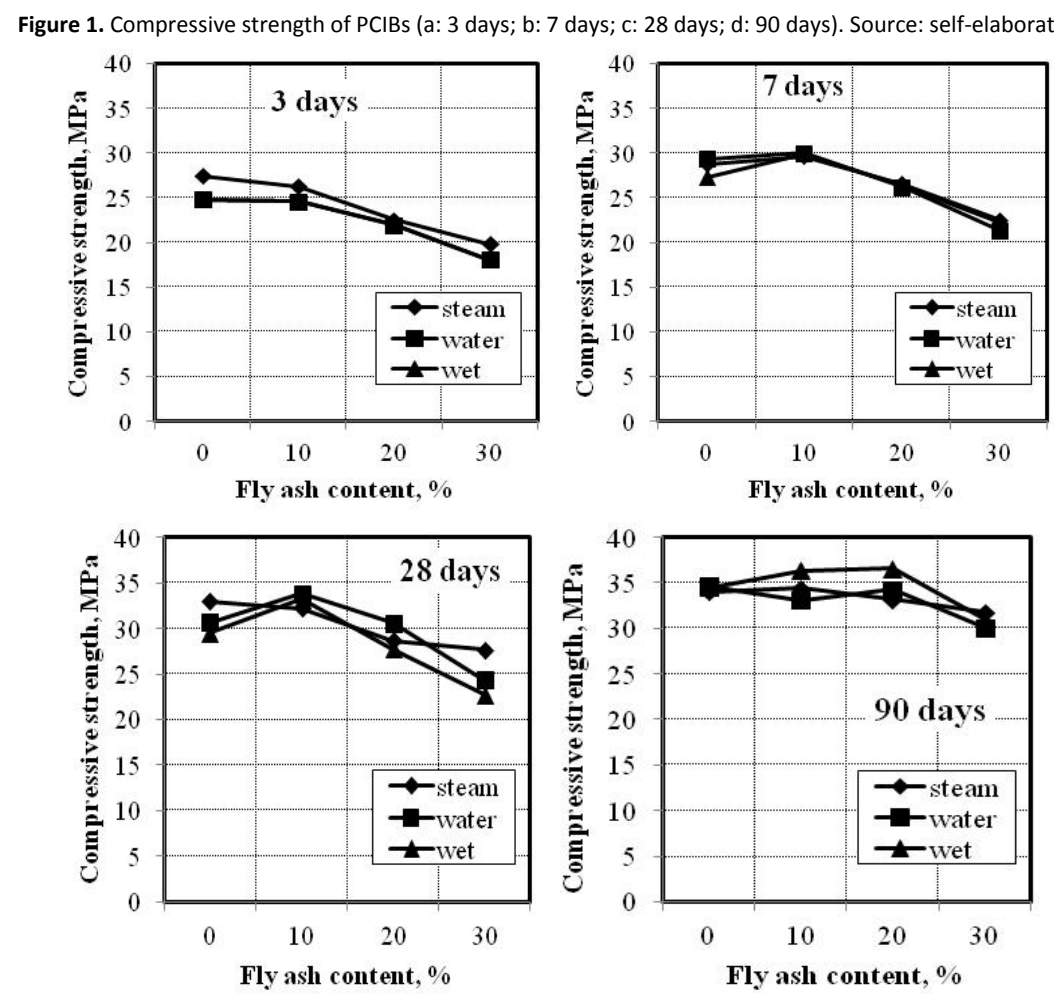

To illustrate, for 3 day, decrease of compressive strength are $1 \%, 11 \%$ and $27 \%$ for $10 \%, 20 \%$ and $30 \%$ fly ash replacement, respectively. Moreover, for 28 day, increase in compressive strength is $10 \%$ for $10 \%$ fly ash content but compressive strength is decrease $26 \%$ for $30 \%$ fly ash replacement in water-cure condition. Similar results are found for wet-cure of PCIBs. The highest compressive strength is obtained in PCIBs with $10 \%$ fly ash ratio to increases $2 \%$ and $10 \%$ at 7 and 28 days in wet-cure condition. However, the compressive strength decreases when fly ash content is increased over to $20 \%$. The strength development of 3 aged PCIBs with fly ash content from 0 to $30 \%$ is $83 \%, 82 \%$, $78 \%$ and $72 \%$, respectively, when compared to strength of 28 aged specimens in steam-cure condition. It is $81 \%$, $73 \%$, 
$72 \%$ and $74 \%$ for blocks that cured in pool cure condition; and is $84 \%, 74 \%, 79 \%$ and $80 \%$ for blocks that cured in wet condition, respectively, as the same fly ash content.

In Figure 1, it is also indicated that the compressive strength of PCIB substantially decreased with the increase of fly ash using ratio from $10 \%$ to $30 \%$. The highest compressive strength values are obtained in $10 \%$ fly ash content for all the curing process. The results demonstrate that fly ash content plays an important role on the strength of PCIBs. On the other hand, it is evident that for a given fly ash ratio, wet cure leads to lower compressive strength value. However, steam and water pool cure on the blocks causes an increase in compressive strength compared with wet cure due to developing of the calcium-silicate-hydrate (C-S-H) gels in humidity. The loss of moisture in the capillary pores due to evaporation or dissipated hydration may cause reduction in hydration resulting in lower strength.

The steam cured samples give higher compressive strength than wet cured samples of concrete (Mannan, Basri, Zain \& Islam, 2002; Toutanji and Bayasi, 1999; Aldea, Young, Wang \& Shah, 2000). The most effectively curing type is steam cure on PCIBs with the highest fly ash ratio. Because the hydration rate of cement increases with the increase in temperature, the gain of strength can be speeded up by curing concrete in steam. Probably, this is due to that new $\mathrm{C}$ $\mathrm{S}-\mathrm{H}$ gels occur with chemical reaction between the calcium hydroxide $(\mathrm{CH})$ and silicates from fly ash. So, under the high temperature and pressure, the chemistry of hydration is changed. $\mathrm{C}-\mathrm{S}-\mathrm{H}$ forms but is converted to a crystalline product a-calcium silicate hydrate $(\alpha-\mathrm{C} 2 \mathrm{SH})$ which resulted to reduce in strength. However, if the presence of silica, $\alpha$ $\mathrm{C} 2 \mathrm{SH}$ is converted to tobermorite $(\mathrm{C} 5 \mathrm{~S} 6 \mathrm{H} 5)$ on continued heating thus increased strength can be obtained (Yazici, 2007). In this study, the silica was obtained from fly ash, especially, in series that including the $30 \%$ mineral admixture.

\section{Splitting strength}

When the effect of fly ash content on splitting strength of PCIB was considered, it can be noted that the splitting strength of concretes showed a considerable decrease depending on increase of fly ash ratio from 0 to $30 \%$ (Figures 2.a-c) as similar to compressive strength. Though the PCIB possess the lowest strength in early ages, they have a satisfactory strength enhancement rate with increase of curing time from 3 to 28 days. The splitting strength for all block specimens increased with time regardless of fly ash using ratio. The range of development in strength of 3 aged PCIBs with fly ash content from 0 to $30 \%$ is $71 \%, 64 \%, 72 \%$ and $63 \%$, respectively, when compared to strength of 28 aged specimens in steam-cure condition. The enhancement in splitting strength after 3 days is $80 \%, 75 \%, 73 \%$ and $61 \%$ for blocks that cured in pool cure condition; and it is $89 \%, 79 \%, 80 \%$ and $61 \%$ for blocks that cured in wet condition, respectively, as the same fly ash content. The curing process is important for the producers as soon as possible due to effective use of production area. Therefore, blocks must be gained strength as soon as possible. However, the ultimate strength is also important, too.

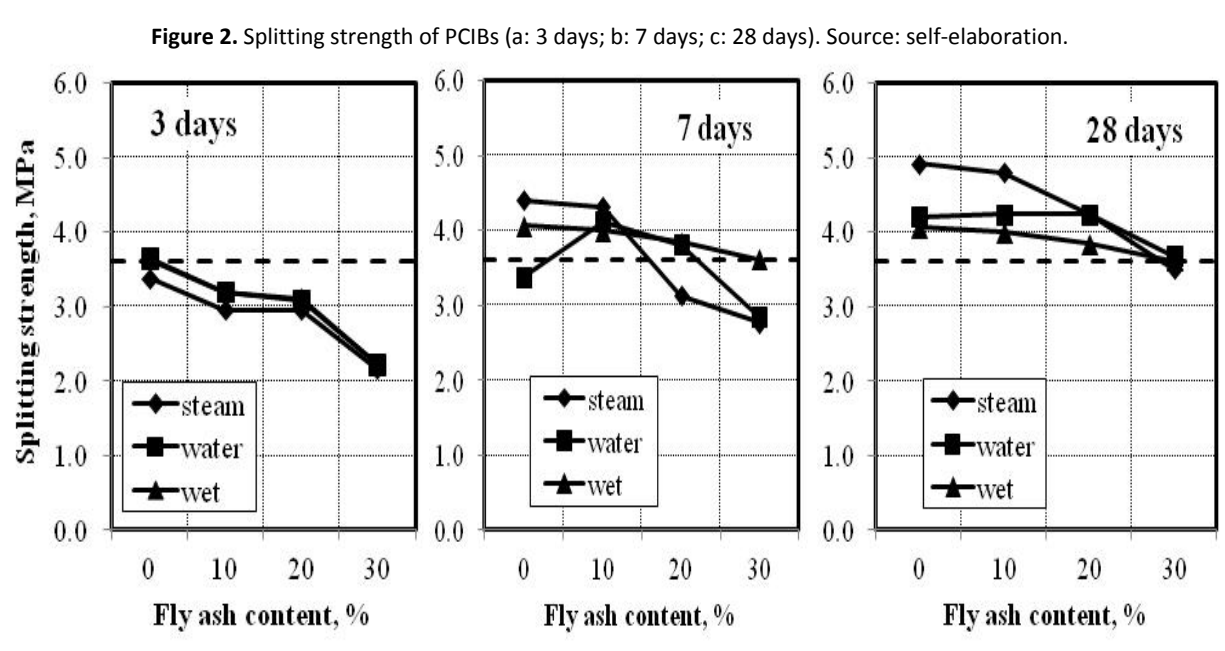

The splitting strength decreases as the fly ash ratio increases for each curing type. In splitting strength of PCIBs after water pool-cure condition, the splitting strength is ranged between 4.2 and $3.8 \mathrm{MPa}$ depending on fly ash using ratio from 0 to $30 \%$ at 28 days. When the splitting strength of blocks cured in steam is changed from 4.92 to $3.5 \mathrm{MPa}$ for blocks cured; and it is changed from 4.06 to $3.61 \mathrm{MPa}$ for blocks cured in wet condition at the same curing time depending on fly ash content. 
As seen, the lowest splitting strength was obtained in PCIBs cured at wet condition at 28 days. This is because the failure of these specimens occurred mainly at the partially weak interfacial zone between cement paste and aggregate. In splitting test, failure of specimens occurs mainly at the weak interfacial zone between cement paste and aggregate because of strength of normal aggregate greater than strength of bond (Uygunoglu et al., 2012; Atici and Ersoy, 2008; Binici et al., 2008). It is well known from the literature that hydration products are occur densely in water cure and steam cure than air or wet cure.

\section{Abrasion resistance}

The abrasion resistance of PCIBs is strongly influenced by the stiffness, compressive strength, surface finishing techniques, curing types, aggregate properties and testing conditions, i.e. dry or wet. The abrasion depths of PCIBs are shown in Fig. 3 depending on curing type, curing age and fly ash content. The test results show that the abrasion depth of the 28 aged PCIBs, produced in fly ash ratio of 0, 10, 20 and 30\% was 21.4, 21.51, 21.28 and $21.4 \mathrm{~mm}$, respectively, after 75 rotations of disc in steam cure. For 28 aged PCIB with pool and wet cure, the abrasion length ranged between 21.19-21.55 $\mathrm{mm}$ and between $21.5-23.3 \mathrm{~mm}$, respectively, depending on mineral admixture ratio. This means that the abrasion resistance of PCIBs cured in water pool and steam is better than that of the wet cure condition regardless of fly ash ratio. This is based upon the fact that denser hydration products are obtained by water and humidity when compared to periodical wet cure (Binici et al., 2007). Furthermore, it must be noted that 28 aged specimens has higher wear resistance than 3 days aged blocks for all the curing type. The reduction in abrasion length value of 28 days aged PCIBs after steam-cure is $4 \%, 10 \%, 11 \%$ and $13 \%$ for fly ash content when comparing the 3 days aged specimens. However, the decrease in the abrasion length of blocks of those cured in the water-pool is $3 \%, 8 \%$, $12 \%$ and $13 \%$; and it was $7.4 \%, 10 \%, 13 \%$ and $12.4 \%$ for 28 days aged specimens that cured in wet condition when compared to abrasion length of early age specimens. The highest amount of abrasion value is obtained at 3 days aged blocks with $30 \%$ fly ash replacement at all the series.
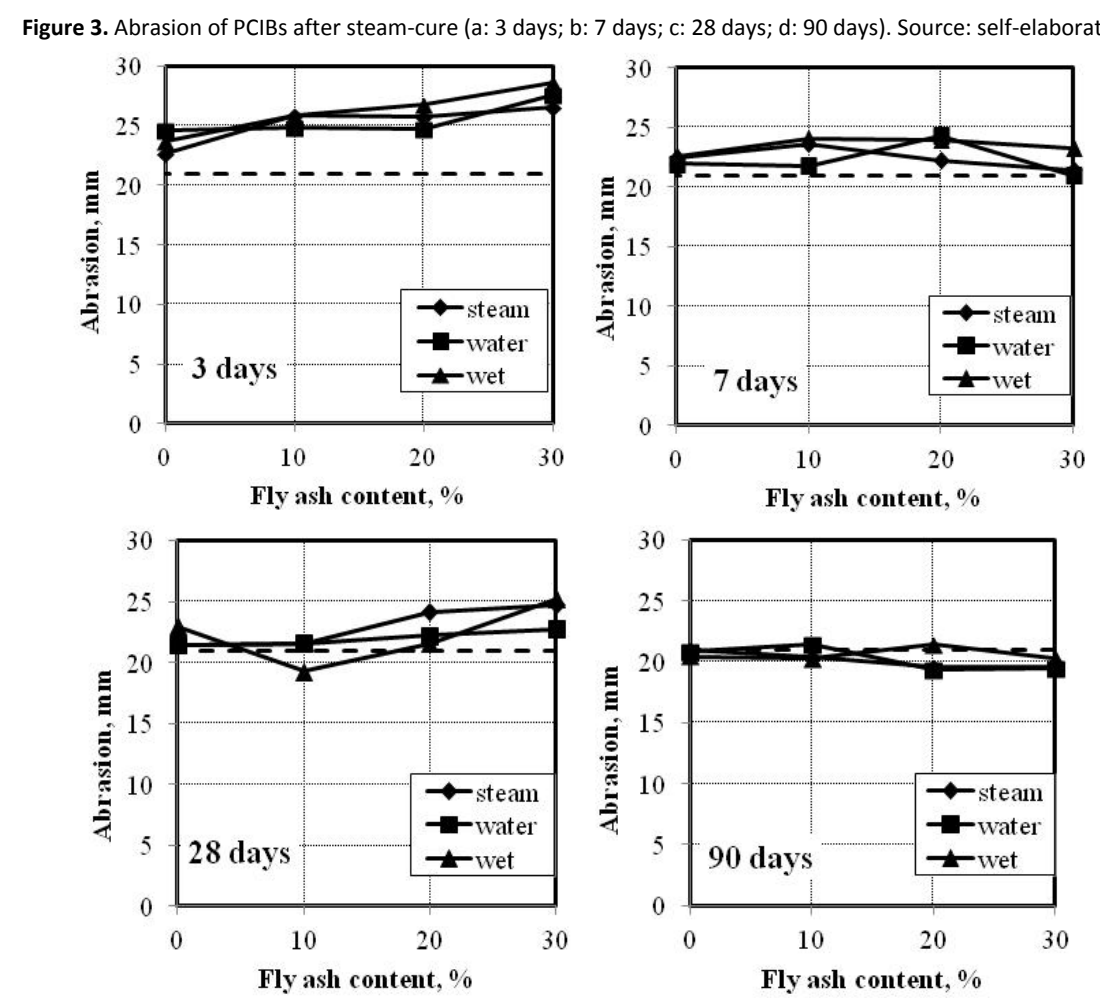

When the effect of the curing type on the abrasion values of the block samples at 28 days was considered, it can be noted that the of abrasion showed a considerable increase depending on the increase in the fly ash ratio from 0 to $30 \%$ for wet cure. However, on abrasion of pavement blocks that cured in steam and pool cure was not changed very much when compared to depending on fly ash content. However, it can be seen that the best curing type is steam cure for the lowest abrasion length. 
The unit weights of pavement blocks were measured at right after 28-day curing for all the curing types. The density of blocks that cured in water-pool varies from 1038 to $1015 \mathrm{~kg} / \mathrm{m3}$. It was changed between $1013-981 \mathrm{~kg} / \mathrm{m3}$ and $1047-$ $1012 \mathrm{~kg} / \mathrm{m} 3$ for pavement blocks that cured at steam and wet condition, respectively (Table 3). It is clearly seen that the highest density is obtained at water-pool and wet cure condition, the lowest density is observed at steam cure condition for all the fly ash replacement ratios. Water is the main cause of the degradation of building materials. It penetrates into porous media, transports harmful substances and freezes inside. When a homogeneous porous material has a constant hydraulic potential at its wet surface, liquid can reach the significant heights and depths due to the absorption-ability (Hanžič and Ilić, 2003; De La Cruz et al., 2015). The variation of the water absorption of PCIBs with fly ash ratio is presented in Figure 17 for all the different type of cure condition. The low absorption is also an indication of good compaction achieved by the vibration. The water absorption increases with increasing fly ash content for all the curing process. The results clearly indicate that fly ash content influences water absorption of PCIBs. It is evident that for a given PCIB series, a lower fly ash replacement ratio leads to lower water absorption, due to the pore structure densification. While the water absorption of PCIB samples with pool cure changed between $0.93 \%$ and $1.27 \%$, it ranged between $1.12 \%-1.3 \%$ and $0.87 \%-1.23 \%$ for pavements that cured in steam and wet condition, respectively. The highest water absorption values are observed on specimens cured in steam for each series.

Table 3. Physical properties of concrete pavement blocks. Source: self-elaboration.

\begin{tabular}{ccccc}
\hline Curing type & Fly ash ratio, \% & Specific prorsity, \% & Water absorption, \% & Unit weight, $\mathbf{~ g g} / \mathbf{m}^{\mathbf{3}}$ \\
\hline Wet cure & 0 & 2,04 & 0,87 & 1047 \\
& 10 & 2,38 & 0,99 & 1031 \\
& 20 & 2,26 & 0,95 & 1034 \\
Steam cure & 30 & 3,17 & 1,23 & 1012 \\
& 0 & 2,62 & 1,12 & 1013 \\
& 10 & 2,61 & 1,12 & 981 \\
Pool cure & 20 & 3,94 & 1,28 & 1004 \\
& 30 & 2,65 & 1,30 & 985 \\
& 0 & 2,95 & 1,13 & 1038 \\
& 10 & 2,61 & 1,27 & 1015 \\
\end{tabular}

In general, the apparent porosity (AP) of each series increased with increasing mineral admixture (Table 4). Maximum AP was obtained at $30 \%$ replacement ratios of fly ash with the Portland cement for all the curing types. The AP value of control specimens was $2.5 \%, 2.6 \%$ and $2 \%$ for pool, steam and wet cure conditions, respectively. Increments of AP of block specimens with $30 \%$ fly ash content was $21 \%, 23 \%$ and $55 \%$, respectively, for the same curing process when compared to AP value of the control specimens. When the curing type is considered, it can be clearly seen that the highest AP values are obtained in PCIBs that cured at steam.

This is to be expected since the concrete members have more amorphous structure when they cured in steam by rapidly than wet or water-pool cure. So, they have strong and high strength at the first time i.e. at the early ages due to the formed hydration by humidity. But their strength is reduced by the time because of irregular distribution of hydrated cement products. This phenomenon leads to increasing of specific porosity and water absorption. On the other hand, slowly cured blocks have stable and therefore denser hydration products than that of steam cured specimens at forward ages. Nevertheless, they have low water absorption and specific porosity values when compare to pavement block values in literature. For example, Garcia et al. (2008) studied the six different experimental pavements with different types of concrete surface finishes include hand finishing, repeated power finishing without spreading dry-shaking hardeners on the concrete and spreading chippings of iron filings, corundum, quartz and cement on it. The water absorption of pavements is ranged from $8.65 \%$ to $10.48 \%$ depending on surface finishing type. Lam et al. (2007) produced to concrete paving blocks with recycled crushed glass (RCG) as an aggregate using the optimal mix proportion, and the corresponding mechanical properties were determined. The experimental findings showed that the pavement blocks have water absorption values that ranged from $2.8 \%$ to $5.4 \%$ depending on mix type. 
The back scattered electron images of the fractured surface of hardened pavement chips are presented in Fig. 4 . The densest structure was observed in the water curing at $20^{\circ} \mathrm{C}$ compared with other curing types. The hardened structure produced by the wet curing was more porous than that produced by the steam and water curing. This suggests that the hardened structure produced by the steam curing was changed by dehydration of it. Aggregated structures of well-crystallized calcium silicate hydrate which be xonotlite and those of small-sized platy crystals which may be gehlenite hydrate were also observed in the structure of steam cured pavement chips. Although structures similar to the structures produced by the wet curing were observed in the water curing, the size of hydrate was generally smaller and the morphology of crystalline calcium silicate hydrate, which seems to be tobermorite, was slightly different from those produced by the water curing.

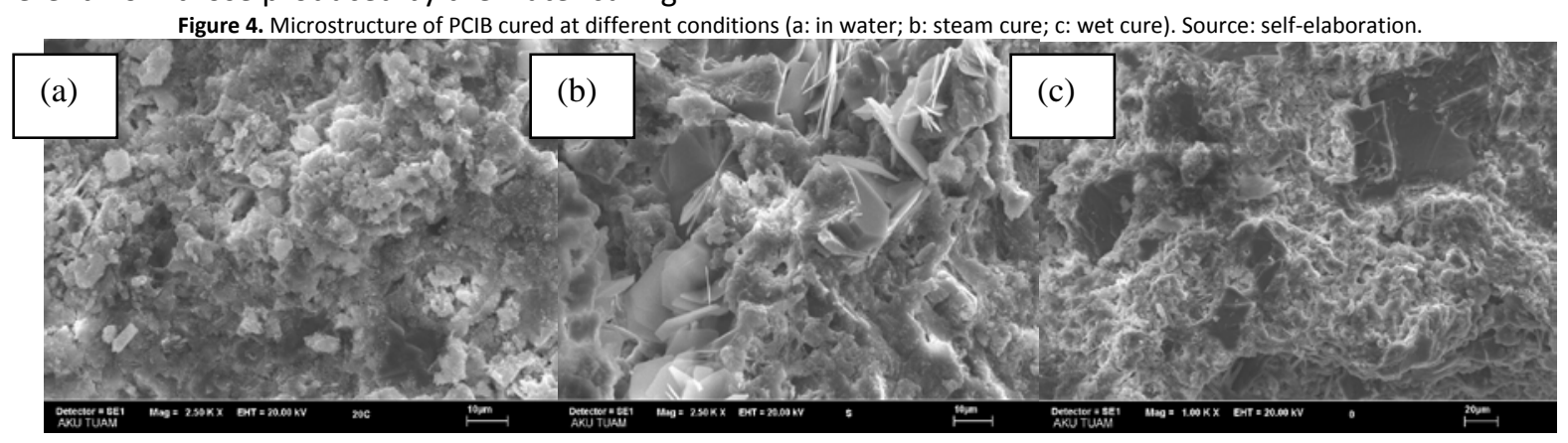

In this paper, the curing factors affecting the properties of concrete blocks were investigated and the results can be summarized as follows:

- In general, the compressive strength decreased with an increase in fly ash using ratio. The highest compressive strength values are obtained in $10 \%$ fly ash content for all the curing process. However, cure condition results change sharply after the $20 \%$ and $30 \%$ fly ash ratio. The compressive strength values of PCIBs are changed between 23 and $34 \mathrm{MPa}$ depending on curing process and fly ash ratio at 28 days.

- The splitting strength also decreases as the fly ash ratio increases for each curing type as similar to compressive strength. In splitting strength of PCIBs, it is ranged between 4.9 and $3.5 \mathrm{MPa}$ at 28 days depending on fly ash using ratio from 0 to $30 \%$ and different curing application. While the lowest splitting strength was obtained in PCIBs cured at wet condition, the highest strength values are obtained that cured at steam for the same pavement ages.

- The abrasion resistance of the blocks was affected by the fly ash ratio. When the fly ash ratio was $30 \%$, the abrasion resistance was marginal. On the other hand, the best curing type is steam cure for the highest abrasion resistance.

- Due to slowly curing process of wet and water-pool conditions stable hydration products occurred in PCIBs, and therefore lower specific porosity and water absorption was obtained than PCIBs with steam cure at forward ages. Nevertheless, they have low water absorption and specific porosity values when compare to pavement block values in literature.

- Curing process plays a significant role in hydration of cement and thus cured strength of pavement blocks. When mechanical properties such as compressive strength, splitting strength and abrasion resistance of 28 days aged PCIBs was considered, it was obtained that the best curing type is steam. It also provides the early strength development and usage of the storage areas effectively for producers.

As a result, to make use of recycled materials to produce eco-friendly concrete blocks with good quality, it is recommended to prepare the blocks with $10 \%$ recycled fly ash and $90 \%$ Portland cement with steam cure process. Pavement blocks with fly ash can be gained higher strength than traditional pavement blocks by steam curing process. 
1338, T. 2824 E. (2009). Concrete paving blocks Requirements and test methods. Ankara, Turkey.

Ahmaruzzaman, M. (2010). A review on the utilization of fly ash. Progress in Energy and Combustion Science, $36(3)$, $327-363$. http://doi.org/10.1016/j.pecs.2009.11.003

Aldea, C. M., Young, F., Wang, K., \& Shah, S. P. (2000). Effects of curing conditions on properties of concrete using slag replacement. Cement and Concrete Research, 30(3), 465-472. http://doi.org/10.1016/S0008-8846(00)00200-3

American Concrete Institute. (1963). Pressure steam curing. ACl Journal, 60(8), 953-986.

ASTM. (2005). Standard Specification for Coal Fly Ash and Raw or Calcined Natural Pozzolan for Use. Annual Book of ASTM Standards. West Conshohocken, PA: ASTM International. http://doi.org/10.1520/C0618-15

ASTM. (2015). Standard Specification for Solid Concrete Interlocking Paving Units. Annual Book of ASTM Standards. West Conshohocken, PA: ASTM International.

Atici, U., \& Ersoy, A. (2008). Evaluation of destruction specific energy of fly ash and slag admixed concrete interlocking paving blocks (CIPB). Construction and Building Materials, 22(7), 1507-1514. http://doi.org/10.1016/j.conbuildmat.2007.03.028

Bahamondes, R., Echaveguren, T., \& Vargas Tejeda, S. (2013). Assessment of pavement concrete blocks design methods. Revista de La Construccion, $12(3), 17-26$.

Bilgin, N., Yeprem, H. A., Arslan, S., Bilgin, A., Gunay, E., \& Marsoglu, M. (2012). Use of waste marble powder in brick industry. Construction and Building Materials, 29, 449-457. http://doi.org/10.1016/j.conbuildmat.2011.10.011

Binici, H., Kaplan, H., \& Yılmaz, S. (2007). Influence of marble and limestone dusts as additives on some mechanical properties of concrete. Scientific Research and Essay, 2(9), 372-379.

Binici, H., Shah, T., Aksogan, O., \& Kaplan, H. (2008). Durability of concrete made with granite and marble as recycle aggregates. Journal of Materials Processing Technology, 208(1-3), 299-308. http://doi.org/10.1016/j.jmatprotec.2007.12.120

Boukendakdji, M., Brooks, JJ., and Wainwright, PJ. (1996) Influences of steam curing on strength, shrinkage and creep of OPC and slag concrete, Proceeding of the International Conference held at the University of Dundee, Scotland, UK, 367-374.

Chindaprasirt, P., Jaturapitakkul, C., \& Sinsiri, T. (2005). Effect of fly ash fineness on compressive strength and pore size of blended cement paste. Cement and Concrete Composites, 27(4), 425-428. http://doi.org/10.1016/j.cemconcomp.2004.07.003

De La Cruz, J. C., Colorado, D., \& Del Campo, J. M. (2015). Comparative study on porosity and permeability of conventional concrete and concrete with variable proportions of natural zeolite additions. Revista de La Construccion, 14(3), 72-78.

Erdem, T. K., Turanli, L., \& Erdogan, T. Y. (2003). Setting time: An important criterion to determine the length of the delay period before steam curing of concrete. Cement and Concrete Research, 33(5), 741-745. http://doi.org/10.1016/S0008-8846(02)01058-X

Garcia, A., Fresno, D. C., \& Polanco, J. A. (2008). Effect of dry shaking treatment on concrete pavement properties. Construction and Building Materials, 22(11), 2202-2211. http://doi.org/10.1016/j.conbuildmat.2007.08.010

Gencel, O., Ozel, C., Filiz, M., \& Koksal, F. (2012). The relations between mechanical strengths and abrasive wear of concrete incorporating the hematite aggregate. International Journal of Pavement Engineering, 13(3), 235-243. http://doi.org/10.1080/10298436.2011.619266

Gesoglu M, Oz HO \& Guneyisi, E. (2012) Properties of lightweight aggregates produced with cold-bonding pelletization of fly ash and ground granulated blast furnace slag. Materials and Structures 45:1535-1546.

Hanzic, L., \& Ilic, R. (2003). Relationship between liquid sorptivity and capillarity in concrete. Cement and Concrete Research, 33(9), $1385-1388$. http://doi.org/10.1016/S0008-8846(03)00070-X

Ho, D. W. ., Chua, C. ., \& Tam, C. . (2003). Steam cured concrete incorporating mineral admixtures. Cement and Concrete Research, 33(4), $595-601$. http://doi.org/10.1016/S0008-8846(02)01028-1

Lam, C. S., Poon, C. S., \& Chan, D. (2007). Enhancing the performance of pre cast concrete blocks by incorporating waste glass ASR consideration. Cement and Concrete Composites, 29(8), 616-625. http://doi.org/10.1016/j.cemconcomp.2007.03.008

Liu, B., Xie, Y., \& Li, J. (2005). Influence of steam curing on the compressive strength of concrete containing supplementary cementing materials. Cement and Concrete Research, 35(5), 994-998. http://doi.org/10.1016/j.cemconres.2004.05.044

Mannan, M. A., Basri, H. B., Zain, M. F. M., \& Islam, M. N. (2002). Effect of curing conditions on the properties of OPS-concrete. Building and Environment, 37(11), 1167-1171. http://doi.org/10.1016/S0360-1323(01)00078-6

Papayianni, I., \& Anastasiou, E. (2010). Production of high-strength concrete using high volume of industrial by-products. Construction and Building Materials, 24(8), 1412-1417. http://doi.org/10.1016/j.conbuildmat.2010.01.016

Rong, Z., Sun, W., \& Zhang, Y. (2010). Dynamic compression behavior of ultra high performance cement based composites. International Journal of Impact Engineering, 37(5), 515-520. http://doi.org/10.1016/j.ijimpeng.2009.11.005

Topcu, I. B., \& Uygunoglu, T. (2007). Properties of autoclaved lightweight aggregate concrete. Building and Environment, $42(12$ ), 4108-4116. http://doi.org/10.1016/j.buildenv.2006.11.024 
Toutanji, H. A., \& Bayasi, Z. (1999). Effect of curing procedures on properties of silica fume concrete. Cement and Concrete Research, 29(4), 497501. http://doi.org/10.1016/S0008-8846(98)00197-5

TS EN 12390-3. (2010). Testing hardened concrete. Compressive strength of test specimens.

Turkel, S., \& Alabas, V. (2005). The effect of excessive steam curing on Portland composite cement concrete. Cement and Concrete Research, 35(2), 405-411. http://doi.org/10.1016/j.cemconres.2004.07.038

Uygunoglu, T., Topcu, I. B., Gencel, O., \& Brostow, W. (2012). The effect of fly ash content and types of aggregates on the properties of prefabricated concrete interlocking blocks (PCIBs). Construction and Building Materials, 30, 180-187. http://doi.org/10.1016/j.conbuildmat.2011.12.020

Wang, Z. (2011a). Influence of fly ash on the mechanical properties of frame concrete. Sustainable Cities and Society, 1(3), $164-169$. http://doi.org/10.1016/j.scs.2011.06.001

Wang, Z. (2011b). Influence of fly ash on the mechanical properties of frame concrete. Sustainable Cities and Society, 1 (3), $164-169$. http://doi.org/10.1016/j.scs.2011.06.001

Yang, Q., Zhang, S., Huang, S., \& He, Y. (2000). Effect of ground quartz sand on properties of high strength concrete in the steam autoclaved curing. Cement and Concrete Research, 30(12), 1993-1998. http://doi.org/10.1016/S0008-8846(00)00395-1

Yazıcı, H. (2007). The effect of curing conditions on compressive strength of ultra high strength concrete with high volume mineral admixtures. Building and Environment, 42(5), 2083-2089. http://doi.org/10.1016/j.buildenv.2006.03.013

Yazıcı, S., \& Arel, H. S. (2012). Effects of fly ash fineness on the mechanical properties of concrete. Academy Proceedings in Engineering Science, 37(3), 389-403.

Zeng, Q., Li, K., Fen chong, T., \& Dangla, P. (2012). Determination of cement hydration and pozzolanic reaction extents for fly ash cement pastes. Construction and Building Materials, 27(1), 560-569. http://doi.org/10.1016/j.conbuildmat.2011.07.007 